\title{
Overprescribing Proton Pump Inhibitors \& A Glimpse on its Side Effects
}

\author{
Mohammed Abubakar*1, Sidra Fatima², Aleena Mahvash ${ }^{3}$ \\ ${ }^{1}$ Department of Internal Medicine, Owaisi Hospital \& Research Centre, India \\ ${ }^{2}$ Gandhi Medical College-Musheerabad, India \\ ${ }^{3}$ Deccan College of Medical Sciences, India
}

Submission: April 07, 2017; Published: May 03, 2017

"Corresponding author: Mohammed Abubakar, Department of Internal Medicine, Owaisi Hospital \& Research Centre, Hyderabad, Telangana 500058, India, Tel: +91 9848025211; Email: drmumtazkhan786@yahoo.com

\section{Mini Review}

Proton pump inhibitors are one of the most frequently prescribed classes of drug in the world because they combine a high level of efficacy with low toxicity. In 2006, expenditure on these drugs was $£ 7$ bn globally [1]. Yet studies consistently show that proton pump inhibitors are being overprescribed worldwide in both primary and secondary care [2]. Between $25 \%$ and $70 \%$ of patients taking these drugs have no appropriate indication. This means that, at the very least, $£ 100 \mathrm{~m}$ from the National Health Service (NHS) budget and almost $£ 2$ bn worldwide is being spent unnecessarily on proton pump inhibitors each year.

The first generic proton pump inhibitor (omeprazole) was introduced in 2002 and now comprises more than four fifths of all prescriptions for proton pump inhibitors in India. In the five years since the introduction of omeprazole, prescriptions for proton pump inhibitors have doubled, although the reasons for this rise are not obvious [3]. Despite this substantial increase in drug usage, the decrease in price means that overall expenditure on proton pump inhibitors has been falling in recent years.

Effective and less expensive alternative drugs, such as $\mathrm{H} 2$ receptor antagonists are available for many patients. Yet prescriptions for proton pump inhibitors have superseded those for all other acid inhibiting agents and now account for over $90 \%$ of the NHS drug budget for treating dyspepsia. Proton pump inhibitors cost more than other agents, which is partly why prescribing guidelines have been drafted in several countries. The National Institute for Health and Clinical Excellence (NICE) published its guidelines on proton pump inhibitors in 2000. Its recommendations for using these drugs particularly in the long term are relatively selective [4]. If prescriptions were restricted to the recommended indications, expenditure on proton pump inhibitors would be far less than $90 \%$ of the total dyspepsia drug budget.
Proton pump inhibitors have been a tremendous therapeutic advance. Especially in the long term, they have transformed the lives of patients with previously intractable symptoms of gastro-oesophageal reflux with its associated complications, and they have also proved valuable for patients who are at risk of iatrogenic upper gastrointestinal pathology. A short term trial of a proton pump inhibitor is also a good option for treating a wide range of acid-peptic conditions. But the drugs are clearly being overused. Some people will point to their combination of superior efficacy and high safety as a justification for using them in preference to drugs such as $\mathrm{H} 2$ receptor antagonists. Yet, side effects should not be overlooked. An increase in the prevalence of pneumonia and Campylobacter enteritis is reported, as well as a doubling of the risk of infection with Clostridium difficile [5]. Acute interstitial nephritis and osteoporosis are unusual but recognised consequences of treatment with proton pump inhibitors.6Such effects are fortunately rare. The adverse effect of over prescription on drug budgets around the world is the real problem. Quite how to motivate doctors to follow guidelines is a matter of considerable importance

\section{Proton pump inhibitors \& hypomagnesemia}

Proton pump inhibitors (PPIs) were introduced to the market for peptic ulcer disease in 1989. Hypomagnesemia was reported for the first time in medical literature as a potential side effect of this class of drugs in 2006. The US Food and Drug Administration released a warning in 2011 [6] about low serum magnesium levels associated with long-term use of PPIs. An analysis of the Food and Drug Administration's Adverse Event Reporting System shows that approximately $1 \%$ of patients experienced hypomagnesemia while on PPIs [7]. Symptoms include seizures, arrhythmias, hypotension, tetany, and death [8]. Despite the evidence, hypomagnesemia related to chronic PPI use was not 
addressed in the 2013 American College of Gastroenterology guidelines [9].

PPIs are widely used, both through prescription and over the counter, and are believed to be safe; however, one of the rare but serious complications is hypomagnesemia. It is well reported in nephrology journals [10]. However, the paucity in the internal medicine literature is amazing and prompted us to present this case. To our knowledge, there have been only 4 case reports of PPI-induced hypomagnesemia resulting in seizures [11]. Magnesium is excreted via renal and gastrointestinal routes. The prime culprit in PPI-induced hypomagnesemia is impaired intestinal absorption [12]. In patients with gastrointestinal malabsorption, $\mathrm{H} 2$ antagonists should be the first-line therapy, or if PPI use is essential, then the patient should be monitored closely for hypomagnesemia, especially for cardiac patients who might have a propensity for arrhythmia. There is a clear correlation between long-term use of PPI and hypomagnesemia, and clinicians need to be aware of it.

\section{Proton pump inhibitors \& in high risk cardiovascular subsets}

Proton-pump inhibitors (PPIs) have been demonstrated to reduce rates of gastrointestinal events in patients requiring dual antiplatelet therapy (DAPT). Data are limited regarding the efficacy and safety of PPIs in high-risk cardiovascular subsets after acute coronary syndrome or percutaneous coronary intervention.PPI therapy attenuates gastrointestinal bleeding risk without significant excess in major cardiovascular events in high-risk cardiovascular subsets, regardless of indication for DAPT. Future studies will be needed to clarify optimal gastroprotective strategies for higher-intensity and longer durations of DAPT.

Hypomagnesemic hypoparathyroidism may develop during long-term PPI therapy [1,2]. Patients can be asymptomatic or present with life-threatening arrhythmias and neuromuscular symptoms; furthermore, hypomagnesemia is refractory to magnesium supplementation until PPIs are withdrawn [13]. Dietary magnesium is largely absorbed in the small bowel, and kidneys play a highly efficient role in its conservation, with $3 \%$ of filtered magnesium lost in the urine, most of which is reabsorbed in the thick ascending limb of the loop of Henley. Mechanisms by which the intestinal and renal handling of magnesium is affected by PPIs are unknown. PPI-induced hypochlorhydria is postulated to impair magnesium solubilization and absorption in the small intestine, ultimately depleting its body stores [14]. Variant alleles of active magnesium transport ion channel TRPM6/7 are associated with subtle malabsorption or persistent leak through the kidneys, which may be further aggravated by PPIs [15]. This might explain why only a minority of PPI-treated patients develop Hypomagnesemic Hypoparathyroidism. However, the lack of any report of hypomagnesemia associated with $\mathrm{H} 2$ blockers does not support a mechanistic role of hypochlorhydria in PPI-induced hypomagnesemia.
Hypomagnesemic hypoparathyroidism has been reported with different PPIs, and our patient had ongoing hypomagnesemia with both omeprazole and pantoprazole. The potential to trigger a subclinical magnesium depletion or an overt deficiency status seems to be a class effect that may apply to all PPIs [16]. If PPIassociated hypomagnesemia is dose-related and if it can recur with rechallenge remains unclear [17]. We underscore the need for close monitoring of blood magnesium levels during longterm PPI therapy. PPI therapy is a rare but fully reversible cause of unexplained hypoparathyroidism

\section{Proton pump inhibitors and risk of fractures}

Concerns have been raised about the risk of fractures with acid-suppressive medications, such as proton pump inhibitors and histamine2-receptor antagonists. In this meta-analysis of observational studies, proton pump inhibitors modestly increased the risk of hip, spine, and any-site fractures, whereas histamine2-receptor antagonists were not associated with fracture risk. The possibility of residual confounding cannot be excluded. Further skeletal evaluation should be considered for patients who are taking proton pump inhibitors and also at risk for osteoporotic fracture.

\section{References}

1. http://www.imshealth.com/ims/portal/front/

2. Naunton M, Peterson GM, Bleasel MD (2005) Overuse ofproton pump inhibitors. J Clin Pharm Ther 125(4): 333-340.

3. National Health Service (2006) PACT centre pages. Drugs fordy spepsia.

4. www.nice.org.uk/newsevents/pressreleases/pressreleasearchive/ pressreleases2000/2000_022_nice_issues_guidance_on_proton_ pump_inhibitors_ppi_for_dyspepsia.jsp

5. Dial S, Delaney J, Barkun A, Suissa S (2005) Use of gastric acidsuppressive agents and the riskof community-acquired Clostridium difficileassociated disease. JAMA 294(23): 2989-2995.

6. Yang Y, Lewis J, Epstein S,Metz D (2006) Long-term proton pump inhibitor therapy and riskofhip fracture. JAMA 296(24): 2947-2953.

7. Food and Drug Administration (FDA). FDA Drug Safety Communication: Low Magnesium Levels Can be Associated with Long-term Use of Proton Pump Inhibitor Drugs (PPIs). FDA, Silver Spring, MD.

8. Danziger J, William JH, Scott DJ, Lee J, Lehman LW,et al. (2013) Proton-pump inhibitor use is associated with low serum magnesium concentrations. Kidney Int 83: 692-699.

9. Katz PO, Gerson LB, Vela MF (2013) Guidelines for the diagnosis and management of gastroesophageal reflux disease. Am J Gastroenterol 108(3): 308-328.

10. Perazella MA (2013) Proton pump inhibitors and hypomagnesemia: a rare but serious complication. Kidney Int 83(4): 553-556.

11. Mackay JD, Bladon PT (2010) Hypomagnesemia due to proton pump inhibitor therapy: a clinical case series. Q J Med 103(6): 387-395.

12. Bai JP, Hausman E, Lionberger R, Zhang X (2012) Modeling and simulation of the effect of proton pump inhibitors on magnesium homeostasis. Mol Pharm 9(12): 3495-3505.

13. Hoorn EJ, van der Hoek J, de Man RA, Kuipers EJ, Bolwerk C, et al. (2010) A case series of proton pump inhibitor-induced hypomagnesaemia. Am J Kidney Dis 56(1): 112-116 
14. Swaminathan R (2003) Magnesium metabolism and its disorders. ClinBiochem Rev 24(2): 47-66.

15. Quamme GA (2008) Recent developments in intestinal magnesium absorption. CurrOpin Gastroenterol 24(2): 230-235.

16. Gau JT, Yang YX, Chen R, Kao TC (2012) Uses of proton pump inhibitors and hypomagnesemia. Pharmacoepidemiol Drug Saf 21(5): 553-559.

17. Quasdorff M, Mertens J, Dinter J, Steffen HM (2011) Recurrent hypomagnesaemia with proton-pump inhibitor rechallenge. Ann Intern Med 155(6): 405-407.

\section{Your next submission with JuniperPublishers} will reach you the below assets

- Quality Editorial service

- Swift Peer Review

- Reprints availability

- E-prints Service

- Manuscript Podcast for convenient understanding

- Global attainment for your research

- Manuscript accessibility in different formats

( Pdf, E-pub, Full Text, audio)

- Unceasing customer service

Track the below URL for one-step submission https://juniperpublishers.com/online-submission.php 